\title{
PKM BAGI GURU SMP YANG MENGALAMI KESULITAN MENGGUNAKAN SOFTWARE GEOGEBRA DALAM PEMBELAJARAN MATEMATIKA
}

\author{
Yulianto Wasiran ${ }^{1)}$, Ibnu Maja ${ }^{2)}$, Farida Husien ${ }^{3)}$ \\ 1,2,3 UP. MPK Politeknik Negeri Sriwijaya \\ Email: yulianto@polsri.ac.id ${ }^{1}$, ibnumaja@polsri.ac.id ${ }^{2}$
}

\begin{abstract}
One reason is that the process of learning mathematics related to geometry is not yet optimal, it is the difficulty of the teacher to visualize abstract geometrical objects. Geogebra software can be used as a tool to construct, demonstrate or visualize abstract problems in learning geometry material. The problem faced by partners in implementing the geometry learning process by using Geogebra's assistance as a learning medium is the low knowledge of teachers in the use of Geogebra software and the low skills of teachers in using Geogebra software in learning geometry material. In an effort to overcome partner problems, the solution offered was to provide training and assistance to the Geogebra application to junior high school mathematics teachers in Banyuasin III to assist them in the process of learning mathematics. This activity includes theory, practice, and exercises given to participants so that skilled participants use Geogebra. This activity has succeeded in increasing teacher skills in knowledge and skills using Geogebra software for Mathematics learning. Participants understand the use of this software and are also skilled at using it for learning geometry material. This activity has also produced several instructional materials for Geogebra software assisted geometry materials.
\end{abstract}

Keyword: Geogebra, Geometry, Learning, Trainning

\section{PENDAhUluan}

Sebagaimana objek-objek matematika lainnya, objek geometri juga bersifat abstrak, sifatnya yang abstrak dapat menjadi penyebab kesulitan siswa dalam mempelajari materi geometri. Objek-objek dalam pembelajaran geometri yang bersifat abstrak membuat siswa memperoleh beban kognitif yang lebih berat untuk mempelajari materi tersebut. Selama ini pembelajaran geometri di kelas tersebut hanya diajarkan menggunakan media papan tulis dan belum memanfaatkan media pembelajaran seperti komputer. Penyampaian materi yang sering dilakukan guru adalah berupa pembelajaran konvensional seperti ceramah, sehingga ada siswa yang mengalami kesulitan untuk memahami materi yang disampaikan. Fakta di lapangan menunjukkan bahwa keterampilan guru dalam memanfaatkan aplikasi teknologi masih belum cukup memuaskan, termasuk dalam mengajarkan topik-topik matematika yang membutuhkan kemampuan berpikir abstrak seperti geometri. Banyak guru yang merasa kesulitan memvisualisasikan konsep geometri melalui media pembelajaran. Untuk itu dibutuhkan media lain yang dapat membantu pemahaman siswa mengenai geometri tersebut. Seiring dengan perkembangan IPTEK, penggunaan teknologi komputer pada pembelajaran matematika di sekolah telah menjadi salah satu pilihan untuk menyampaikan konsep yang bersifat abstrak menjadi lebih konkret. Sebagai contoh penggunaan komputer dalam pembelajaran matematika adalah penggunaan software Geogebra.

Software Geogebra dapat dimanfaatkan sebagai alat bantu untuk mengonstruksi, mendemonstrasikan atau memvisualisasikan masalah abstrak pada matematika yang tidak dapat diselesaikan secara manual khususnya pada bidang geometri. Geogebra adalah software matematika yang dinamis dan bersifat open source (free) untuk 
pembelajaran dan pengajaran matematika di sekolah. Di samping itu, perangkat lunak Geogebra juga sangat mudah dioperasikan karena menggunakan sintaks atau perintah yang sangat sederhana. [1], mengemukakan bahwa program Geogebra memungkinkan visualisasi sederhana dari konsep geometris yang rumit dan membantu meningkatkan pemahaman siswa tentang konsep. Selain memudahkan guru dalam penyampaian materi, siswa juga lebih mudah menangkap apa yang dijelaskan [1]. Kelebihan program Geogebra dalam pembelajaran matematika antara lain sebagai berikut: (1) dapat menghasilkan lukisan-lukisan geometri dengan cepat dan teliti dibandingkan dengan menggunakan pensil, penggaris, atau jangka. (2) Adanya fasilitas animasi dan gerakangerakan manipulasi (dragging) pada program Geogebra dapat memberikan pengalaman visual yang lebih jelas kepada siswa dalam memahami konsep geometri. (3) Dapat dimanfaatkan sebagai balikan/evaluasi untuk memastikan bahwa lukisan yang telah dibuat benar. (4) Mempermudah guru/siswa untuk menyelidiki atau menunjukkan sifat-sifat yang berlaku pada suatu objek geometri [2]. Berdasarkan kelebihan dan berbagai fasilitas yang ada pada software Geogebra, maka software ini banyak dimanfaatkan sebagai alat bantu untuk mengonstruksi, mendemonstrasikan atau memvisualisasikan masalah abstrak pada matematika [3]. Visualisasi geometris ini akan membuat siswa yang mempunyai daya imajinasi kurang akan dapat mengikuti proses pembelajaran matematika yang notabene kebanyakan bersifat abstrak karena begitu mudahnya visualisasi Geogebra ini dapat dilihat.

Pemanfaatan Geogebra dalam pembelajaran matematika adalah salah satu alternatif strategi pembelajaran yang cukup inovatif [4]. Namun semua itu tergantung dari bagaimana kreativitas dan kemampuan guru mengolah materi menjadi lebih menarik menggunakan Geogebra. Peran guru sangat penting dalam memanfaatkan Geogebra dalam pembelajaran, sehingga guru perlu memaksimalkan penggunaan positif software ini. Akan tetapi masih banyak guru yang belum bisa memanfaatkan aplikasi tersebut. Kemampuan guru dalam memanfaatkan aplikasi tersebut untuk pembelajaran perlu di tingkatkan. Fakta di lapangan menunjukkan bahwa keterampilan guru dalam memanfaatkan aplikasi teknologi masih belum cukup memuaskan, termasuk dalam mengajarkan topik-topik matematika yang membutuhkan kemampuan berpikir abstrak seperti geometri. Guru masih kesulitan dalam membuat media visual yang melibatkan gambar geometri maupun grafik suatu persamaan karena keterbatasan penguasaan software yang relevan. Guru masih mengalami kesulitan dalam membuat bahan ajar terutama yang berkaitan dengan materi gambar geometri. Survey terhadap para guru Matematika SMP pada MGMP Matematika Banyuasin III menunjukkan bahwa para guru belum pernah mendapat kesempatan memperoleh materi Geogebra baik melalui pelatihan mapun workshop. Bahkan mereka baru pertama mendengar software Geogebra. Sebagian besar guru matematika pada MGMP Matematika Banyuasin I sama sekali belum pernah menggunakan perangkat lunak Geogebra dalam pembelajaran matematika di kelas. Diinformasikan pula bahwa keterlibatan guru dalam mengikuti pelatihan tingkat provinsi atau tingkat nasional masih sangat jarang sehingga kemampuan guru dalam memanfaatkan software-software matematika dalam pembelajaran khususnya dalam visualisasi objek-objek matematika masih sangat rendah.

Berdasarkan analisis situasi yang telah diuraikan sebelumnya dan wawancara dengan para guru MGMP Matematika SMP Banyuasin III serta didukung oleh hasil kuesioner, diperoleh simpulan bahwa sebagian besar guru mata pelajaran Matematika tingkat SMP di Banyuasin III belum banyak memanfatkan software Geogebra dalam pembelajaran. Perumusan masalah sebagai berikut: Pengetahuan guru Matematika SMP di Banyuasin IIII dalam penggunaan software Geogebra masih rendah. (b) Keterampilan guru Matematika tingkat SMP di Banyuasin III dalam pemanfaatan software Geogebra pada pembelajaran Matematika masih rendah dan (c) Kesempatan untuk mengikuti kegiatan pelatihan merancang dan memanfaatkan media pembelajaran matematika berbantuan 
software-software matematika sangat jarang mereka dapatkan.

Berdasarkan analisis situasi dan permasalahan yang dihadapi oleh mitra, maka dosen Politeknik Negeri Sriwijaya sebagai pelaksana kegiatan pengabdian yang dibantu oleh 3 mahasiswa memberikan suatu solusi untuk mengatasi kesulitan guru dalam memanfaatkan software untuk visualisasi objek-objek matematika. Adapun solusi yang dilakukan dalam rangka meningkatkan keterampilan para guru dalam penggunaan software Geogebra untuk pembelajaran Matematika, dilakukan melalui pelatihan dan pendampingan penggunaan software Geogebra bagi guru-guru Matematika SMP di kecamatan Banyuasin III.

Kegiatan ini dilakukan untuk meningkatkan kualitas para guru dalam pemanfaatan software Geogebra pada pembelajaran matematika SMP. Dengan menguasai aplikasi ini diharapkan para guru dapat mengimplementasikan pengajaran matematika dengan aplikasi Geogebra sehingga dapat membantu menjelaskan konsep-konsep yang cukup rumit dalam matematika. Beberapa tujuan yang ingin dicapai dalam pelatihan tersebut diantaranya: (1) mengenalkan, menggunakan dan memanfaatkan Geogebra sebagai salah satu alat bantu dalam pembelajaran matematika, (2) memberikan tambahan pengetahuan dan keterampilan di bidang TIK bagi para guru sehingga dapat memberikan kemudahan bagi para guru dalam usaha menyusun materi/bahan ajar pembelajaran matematika yang berdampak pada peningkatkan pemahaman siswa pada materi matematika yang diberikan. Melalui pelatihan yang dilakukan guru diharapkan dapat mendesain pembelajaran matematika menggunakan pengintegrasian Geogebra sebagai alat yang dapat digunakan untuk membantu dalam membuat bahan ajar matematika dan meyelesaikan soal matematika. Selanjutnya target yang ingin dicapai melalui kegiatan penyuluhan, pengenalan, pelatihan dan pendampingan aplikasi software geometri bagi guru matematika SMP di kecamatan Banyuasin III ini adalah : meningkatkan pengetahuan dan keterampilan guru dalam memanfatkan software Geogebra untuk pembelajaran matematika dalam upaya untuk meningkatkan kompetensi profesionalnya. Setelah mencoba, para guru matematika diharapkan mampu menyusun bahan ajar berbantuan software Geogebra dalam membantu proses berpikir matematis siswa.

\section{METODE PELAKSANAAN}

Kegiatan pengabdian masyarakat kerjasama mahasiswa ini dilaksanakan pada bulan Juli-Agustus 2018, bertempat di SMP Negeri 1 Banyuasin III Kabupaten Banyuasin. Transfer ipteks dilakukan melalui kegiatan pelatihan dan pendampingan yang berkaitan dengan pemanfaatan aplikasi Geogebra dalam pembelajaran matematika. Pelaksanaan kegiatan pengabdian ini dikemas dalam bentuk participant active learning. Hal ini dimaksudkan agar peserta memiliki pengalaman langsung dalam mengoperasikan Geogebra. Penyampaian materi dilakukan melalui ceramah, diskusi, penugasan dan simulasi dalam bentuk teori, praktik, dan latihan-latihan yang diberikan kepada peserta agar peserta terampil menggunakan Geogebra. Pelatihan ini dibagi menjadi 3 sesi, yaitu a) pelatihan cara menginstalasi software Geogebra pada komputer/laptop. b) pelatihan pengenalan menu-menu pada Geogebra dan kegunaan dari masing-masing menu dan cara mengoperasikan program Geogebra, c) Pelatihan cara mengintegrasikan Geogebra dalam pembelajaran Matematika d) cara mengembangkan bahan ajar matematika berbasis Geogebra.

Kegiatan pendampingan dilakukan
dengan cara melaksanakan praktek mengaplikasikan software Geogebra yang dilaksanakan oleh para guru. Hal ini dimaksudkan agar kegiatan pengabdian ini dirasakan oleh peserta pada sampai pada tahap praktis, bukan sekedar teoretis. Kegiatan pendampingan dilakukan melalui konsultasi dan bimbingan secara tatap muka dan online.

Refleksi dilakukan bersama antara tim dan mitra. Hal ini dilakukan untuk mengetahui seluruh proses pelaksanaan kegiatan. Mitra dan tim secara bersama melakukan refleksi untuk memberikan saran dan masukkan dari kegiatan pengabdian yang dilakukan. Selain memberikan feedback, peserta juga diberikan arahan bagaimana 
membangun bahan penelitian terkait dengan pemanfaatan software-software matematika sebagai media pembelajaran. Kegiatan observasi dilakukan secara langsung oleh tim pelaksana.

Observasi berupa hasil kerja peserta (guru mitra) terhadap pemanfaatan software dan pemanfaatan media alternatif dalam pembelajaran matematika. Proses evaluasi dilaksanakan untuk mengetahui kekurangan dan kendala dalam pelaksanaan kegiatan pengabdian dan membahas proyeksi pengabdian berikutnya berdasarkan refleksi dari pengabdian yang telah dilakukan. Evaluasi program, dilakukan sebelum dan setelah kegiatan dilaksanakan. Evaluasi ini bertujuan untuk mengetahui apakah program kegiatan sudah sesuai dengan tujuan yang akan dilaksanakan. Evaluasi proses, dilakukan pada saat kegiatan dilaksanakan. Aspek yang dievaluasi adalah kehadiran dan aktivitas peserta dalam mengikuti pelatihan. Evaluasi hasil, dilaksanakan pada akhir kegiatan. Aspek yang dievaluasi adalah pengetahuan dan kemampuan peserta dalam memanfaatkan Geogebra pada pembelajaran matematika.

\section{HASIL DAN PEMBAHASAN}

Seluruh tahapan dalam kegiatan pengabdian ini telah dilaksanakan. Pelatihan ini diikuti 15 orang guru matematika dari beberapa SMP negeri dan swasta yang tergabung dalam MGMP Matematika SMP Banyuasin III. Pada tahap awal pelaksana kegiatan telah disampaikan materi terkait pengenalan Geogebra meliputi apa itu Geogebra, peranan Geogebra dalam pembelajaran matematika, dan fitur-fitur yang dimiliki oleh program ini. Selanjutnya setiap guru disalinkan software Geogebra kemudian para guru dibimbing untuk melakukan instalasi program Geogebra dengan dibantu mahasiswa sampai proses intalasi sukses dilakukan. Setelah proses instalasi selesai dilakukan selanjutnya melalui ceramah dan praktek para guru diajarkan cara menjalankan program dan mencoba berbagai fitur yang tersedia dalam program Geogebra. Secara singkat guru-guru dikenalkan cara membuat objek-objek geometri seperti titik, garis, dan bidang secara one click ataupun dengan cara memasukkan persamaan aljabar.
Selanjutnya, kegiatan fokus pada penggunaan Geogebra dalam pembelajaran geometri. Kegiatan ini meliputi teori, praktik, dan latihan-latihan yang diberikan kepada peserta agar peserta terampil menggunakan Geogebra sebagai media pembelajaran. Fasilitas software yang digunakan disesuaikan dengan topik-topik materi ajar matematika dan kebutuhan para peserta sesuai sub-sub pokok bahasan matematika SMP. Setelah guru-guru sudah paham materi dasar Geogebra, selanjutnya pembuatan bahan ajar matematika berbantuan Geogebra.

Pada akhir kegiatan,para guru dipersilakan untuk mempresentasikan materi dengan sub-pembelajaran yang telah mereka buat untuk mendapatkan masukan baik dari instruktur/pelatih maupun dari teman sejawatnya. Selanjutnya adalah kegiatan simulasi implementasi Geogebra dalam pembelajaran. Simulasi ini sangat penting agar peserta diberi kesempatan mempraktikkan materi yang diperoleh secara teknis kemudian mengidentifikasi kesulitankesulitan (jika ada) untuk diselesaikan.

Pada awalnya guru-guru beranggapan bahwa aplikasi software Geogebra sulit, tetapi setelah dilaksanakannya pelatihan, guru-guru sangat senang dan merasa terbantu dalam melaksanakan proses pembelajaran. Pada saat peserta berlatih atau melakukan praktek secara individu membuat proyek mengembangkan perangkat pembelajaran berbasis software Geogebra, hampir seluruh peserta mengalami kesulitan menggunakan fitur-fitur atau perintah pada Geogebra dalam mengonstruksi bentuk-bentuk geometri. Hal ini dapat dimaklumi karena seluruh peserta belum terbiasa menggunakan software Geogebra. Untuk mengatasi masalah ini peserta diarahkan untuk melihat petunjuk pemanfaatan Geogebra yang sudah diberikan.

Dengan arahan dari narasumber maka secara perlahan seluruh peserta sudah mulai bisa menggunakan perintah-perintah dan menu-menu pada Geogebra dengan baik. Dengan adanya modul petunjuk pemanfaatan Geogebra yang diberikan dan dengan diberikannya pendampingan secara intensif maka seluruh peserta telah mampu membuat sebuah proyek sederhana yang bisa 


\section{2 ptokmas}

durmal Pongabditan Kepada Wlasyamakats

diimplementasikan di kelas pada saat pelaksanaan pembelajaran matematika.

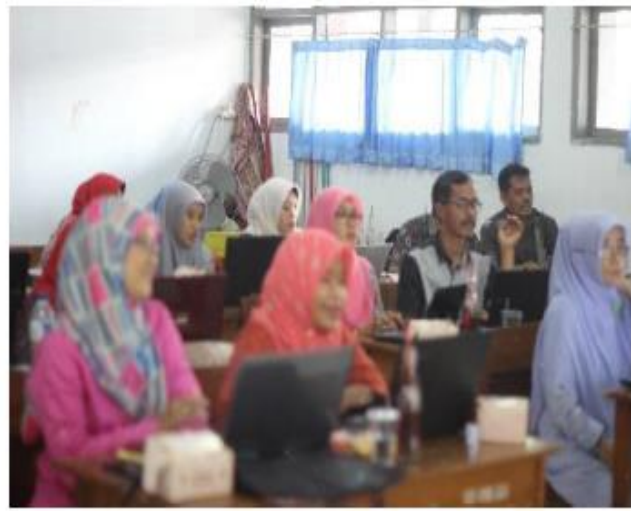

Gambar 1. Peserta Pelatihan

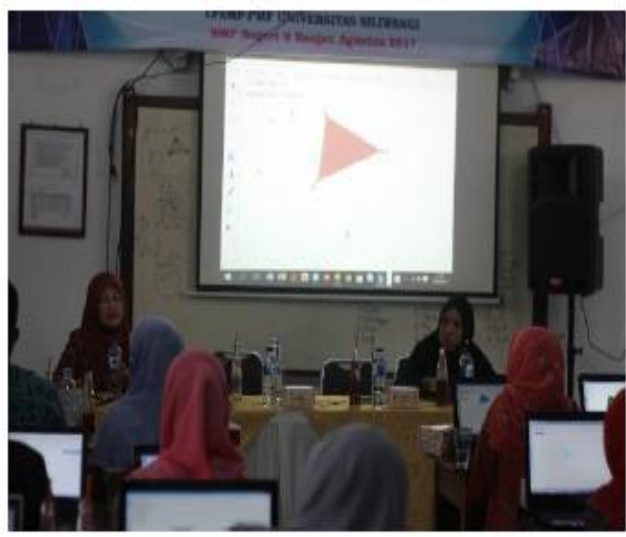

Gambar 2. Aktivitas Simulasi

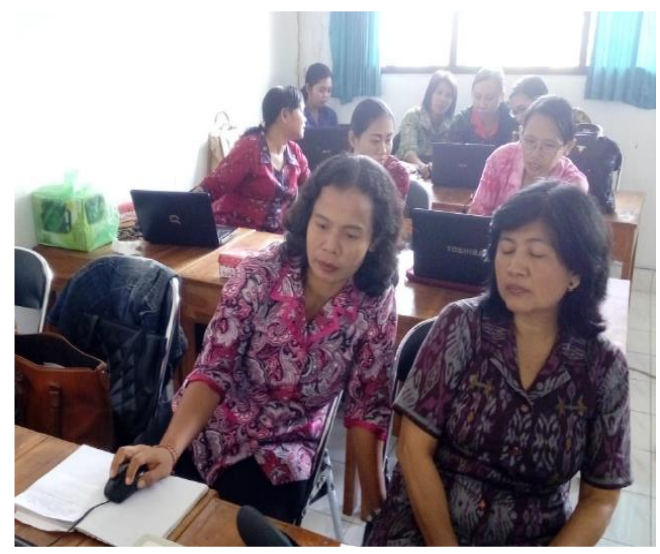

Gambar 3. Kegiatan Diskusi
Volume 2, Nomor 2, (2019)

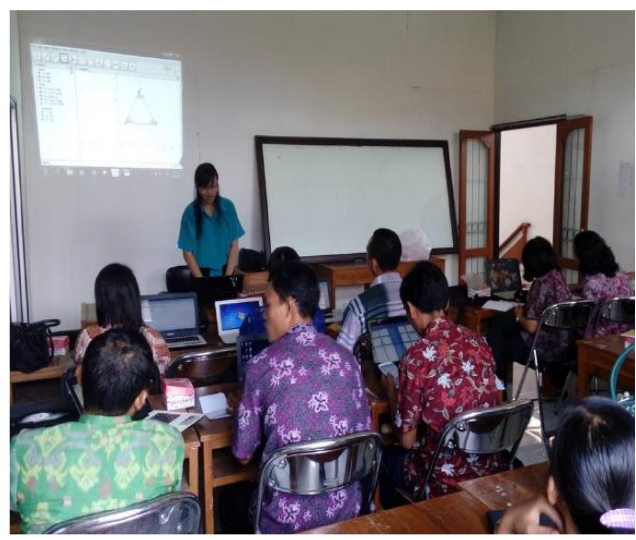

Gambar 4. Kegiatan Evaluasi

Pelaksanaan pengabdian ini mendapatkan perhatian yang positif karena mereka merasa sangat butuh dengan materi yang disampaikan untuk diaplikasikan dalam pembelajaran sehari-hari di kelas. Selama kegiatan berlangsung, peserta terlihat antusias dalam mencoba Geogebra sebagai alternatif media ajar. Sebanyak $83 \%$ peserta menyatakan bahwa pelatihan Geogebra yang diberikan sangat bermanfaat bagi peserta selaku guru-guru matematika.Terkait kesesuaian dengan kebutuhan peserta sebagai guru matematik, $85 \%$ guru menyatakan program pelatihan aplikasi Geogebra untuk pembelajaran matematika ini sesuai dengan harapan, sehingga respon positif mengalir dari para peserta pelatihan. Manfaat dari hasil pelatihan telah langsung dapat dirasakan oleh para guru untuk keperluan pengembangan proses pembelajaran yang ada di sekolah. Para peserta sangat terbantu dalam kegiatan pelatihan dengan pendampingan para pemateri pada saat praktik penggunaan Geogebra dalam pembelajaran. Sebanyak $60 \%$ dari peserta menyatakan bahwa praktik penggunaan Geogebra yang diberikan masih dirasakan kurang karena waktu sangat terbatas. Berkaitan dengan pengadaan modul sebagai materi pelatihan, $91 \%$ peserta menganggap sangat membantu. Berdasarkan saran dari para peserta, mereka mengharapkan ada pelatihan Geogebra berikutnya yang waktu pelatihannya lebih lama dengan topik materi yang lebih menarik lagi yang diharapkan dapat menunjang para peserta dalam mempersiapkan materi pembelajaran Matematika di SMP. Berdasar hasil evaluasi, $55 \%$ peserta menyatakan menginginkan 
diadakan pelatihan Geogebra yang lebih mendetail dan fokus pada satu materi geometri tertentu. Selain itu, $66 \%$ peserta menginginkan pelatihan mengenai software matematika yang lain untuk mendukung pembelajaran berbasis teknologi dan informasi.

Secara keseluruhan kegiatan pengadian pada masyarakat ini mampu memberikan dampak yang signifikan. Kegiatan ini telah berhasil meningkatkan keterampilan guru dalam pengetahuan dan keterampilan menggunakan Geogebra untuk pembelajaran matematika. Peserta mengetahui penggunaan software ini dan sekaligus terampil menggunakannya untuk pembelajaran. Hal ini ditunjukkan hasil penilaian pretest dan postest dari peserta. Dapat diperlihatkan bahwa rata-rata nilai Pretest peserta pelatihan adalah 49,01. dan rata-rata nilai postest adalah 78,89 . Hasil ini menunjukkan adanya peningkatan yang cukup signifikan. Analisis Paired Test memperlihatkan bahwa terjadi perbedaan yang signifikan mengenai kemampuan menggunakan software Geogebra para peserta sebelum dan setelah pelatihan. Dengan memperhatikan nilai $t_{\text {hitung }}$ sebesar 6,725 dan nilai $t_{\text {tabel }}$ pada $\alpha=0,05$ dan $\mathrm{dk}=15-1=14$ sebesar 2,14. Karena nilai thitung lebih besar dari nilai $t_{\text {tabel }}$ maka Ho ditolak, yang dapat diartikan bahwa terdapat perbedaan kemampuan menggunakan software Geogebra sebelum dan sesudah diselenggarakannya kegiatan.

\section{KESIMPULAN}

Berdasarkan hasil pelaksanaan kegiatan pelatihan dan pendampingan pemanfaatan Geogebra dalam pembelajaran materi geometri bagi guru-guru MGMP SMP Banyuasin III diperoleh kesimpulan sebagai berikut:

a) Berdasarkan respon peserta pelatihan yang tertuang dalam isian angket, diketahui bahwa seluruh peserta menyatakan bahwa kegiatan yang dilaksanakan sesuai dengan tujuan yang ingin dicapai yakni meningkatkan pengetahuan dan kemampuan guru matematika SMP Banyuasin III dalam menggunakan
Geogebra dalam pembelajaran materi geometri.

b) Pemahaman pengetahuan guru tentang software Geogebra dalam pembelajaran materi geometri meningkat.

c) Keterampilan para guru dalam memanfaatkan Geogebra untuk pembelajaran matematika meningkat.

d) Guru mampu menyusun bahan ajar materi geometri menggunakan software Geogebra sebagai media.

Selanjutnya, dari kegiatan pelatihan ini, tim pengabdian memberikan beberapa saran sebagai berikut:

(a) Kegiatan pelatihan Geogebra dapat berlanjut dengan pelaksanaan yang lebih mendetail sampai dengan pembimbingan terhadap guru dalam menyusun perangkat pembalajaran sampai dengan praktek di kelas.

(b) Kegiatan pelatihan Geogebra dilakukan untuk materi matematika yang lain (yang masih memungkinkan untuk disampaikan dengan menggunakan Geogebra).

\section{UCAPAN TERIMA KASIH}

Keterlaksanaan kegiatan PPM melibatkan banyak pihak baik yang mendukung dengan berbagai bantuan baik bantuan fisik maupun non-fisik. Oleh karenanya, ucapan terima kasih ditujukan kepada Direktur dan Kepala PPPM Politeknik Negeri Sriwijaya yang telah mendanai kegiatan pengabdian pada masyarakat ini melalui dana DIPA Politeknik Negeri Sriwijaya tahun 2018 melalui kontrak nomor: 3830/PL6.2.1/PM/2018 tanggal 2 Mei 2018. Terima kasih juga disampaikan kepada ketua UP.MPK Politeknik Negeri Sriwijaya, para mahasiswa yang terlibat dalam kegiatan pengabdian masyarakat ini serta kepada kepala MGMP Matematika SMP Banyuasin III dan para peserta, atas bantuan komunikasi dan distribusi informasi dari Tim PPM ke peserta dan sebaliknya, dan para guru mitra yang menjadi peserta atas peran aktifnya dalam kegiatan pengabdian pada masyarakat ini. 


\section{REFERENSI}

[1] Aksoy, Y., Bayazit, İ. \& Soybaş, D. 2010. The Effects of GeoGebra in Conjectures and Proofs, First North American GeoGebra Conference, 27 - 28 July 2010, Ithaca, New York, USA.pp. 190-195.

[2] Hohenwarter, M. \& Fuchs, K. 2004. Combination of Dynamic Geometry, Algebra, and Calculus in the Software System Geogebra. Tersedia: www. geogebra.org/publications/pecs_2004.pdf . [16 Juni 2018].
[3] Manizade, A.G and Mason, M. 2011. Choosing Geogebra Applications Most Appropriate For Teacher's Current Geometry Classroom: Pedagogical Perspective. International Journal of Educational Studies in Mathematics, 76(1), pp.214-218.

[4] Preiner, J. 2013. Introducing Dynamic Mathematics Software to Mathematics Teachers: the Case of GeoGebra. Unpublished Doctoral dissertation in Mathematics Education. Faculty of Natural Sciences, Salzburg: University of Salzburg, Austria. 